\title{
Osteomalacia after Prolonged Glutethimide Administration
}

\author{
R. H. GREENWOOD, F. T. G. PRUNTY, J. SILVER
}

British Medical fournal, 1973, 1, 643-645

\section{Summary}

Vitamin D deficiency is a previously unreported complication of therapy with hypnotics, and we here report a case of osteomalacia associated with long-term glutethimide administration. There was evidence of pronounced hepatic enzyme induction, and the plasma half-time of ${ }^{3} H$ vitamin $D_{3}$ was decreased by this drug. In addition, raised levels of serum gamma-glutamyl transpeptidase, 5-nucleotidase, and leucine aminopeptidase were observed and the patient excreted large amounts of xylulose. These changes were reversed by stopping the glutethimide.

\section{Introduction}

The conversion of vitamin $\mathrm{D}_{3}$ into biologically active forms is dependent on its initial hydroxylation in the liver to 25-hydroxycholecalciferol $\left(25-\mathrm{OHD}_{3}\right)$, which is quantitatively the major circulating derivative of vitamin $\mathrm{D}$ (Ponchon and De Luca, 1969). Some $25-\mathrm{OHD}_{3}$ is further metabolized to other biologically active derivatives including 1,25-dihydroxycholecalciferol $\left(1,25-\mathrm{OHD}_{3}\right)$ which is formed in the kidney and, of the metabolites, is most active in promoting intestinal calcium absorption (Lawson et al., 1971). It has been shown that 25hydroxylation may be stimulated by hepatic enzyme-inducing drugs such as phenobarbitone (Hahn et al., 1972; Silver et al., 1972a), but it has also been suggested that enzyme-induced alterations in vitamin $\mathrm{D}$ metabolism may be related to the increased incidence of vitamin $D$ deficiency found in children on long-term anticonvulsant therapy (Schmid, 1967; Kruse, 1968; Richens and Rowe, 1970) and there have been several case reports of overt vitamin $\mathrm{D}$ deficiency in patients receiving antiepileptic drugs (Dent et al., 1970; Greenlaw et al., 1972; Santangelo et al., 1972). Many hypnotics are also known to be hepatic enzyme inducers but they have not previously been related to vitamin $\mathrm{D}$ deficiency. In this paper we report the investigation of a case of osteomalacia associated with the long-term administration of glutethimide and show an increase in the turnover of ${ }^{3} \mathrm{H}$ vitamin $\mathrm{D}_{3}$ in response to this drug.

\section{Methods}

Calcium balance studies were performed in a metabolic ward as previously described by Prunty et al. (1953), utilizing continous chromium markers to ensure accuracy of stool collections. Serum calcium, phosphate, and alkaline phosphatase were estimated by the S.M.A. 12/60 autoanalyser. The renal phosphate threshold was assessed by a phosphate infusion technique (Hyde et al., 1960) using a continuously accelerating infusion pump. Alkaline phosphatase isoenzymes were measured by the technique of Canapa-Anson and Rowe (1970), serum 5-nucleotidase by that

\section{St. Thomas's Hospital, London SE1 7EH}

R. H. GREENWOOD, B.SC., M.R.C.P., Registrar in Metabolic Diseases

F. T. G. PRUNTY, M.D., F.R.C.P., Professor of Chemical Pathology and Physician

Royal Postgraduate Medical School, London W12 0HS J. SILVER, M.SC., M.R.C.P., Research Fellow in Medicine of Campbell (1962), gamma-glutamyl transpeptidase by the method of Szasz (1969), and leucine aminopeptidase by that of Nagel et al. (1964). Plasma antipyrine was estimated by the technique of Brodie et al. (1949), urinary 6 6 -hydroxycortisol by the method used by Breckenridge et al. (1971), and urinary D-glucaric acid by the method of Hunter et al. (1971). Urinary xylulose was estimated by quantitative paper chromatography.

Studies with ${ }^{3} \mathrm{H}$ vitamin $\mathrm{D}_{3}$ were performed as follows: $6 \mu \mathrm{g}$ of ${ }^{3} \mathrm{H} \mathrm{D}_{3}(4.7 \mu \mathrm{Ci})$ made up in propylene glycol was injected intravenously and blood samples were subsequently collected at intervals for nine hours, then daily for one week, and weekly for one month. Lipid extracts of plasma were chromatographed on a silicic acid column (Mawer and Backhouse, 1969) thus separating radioactivity eluted as vitamin $D_{3}$ from that of $25-$ $\mathrm{OHD}_{3}$ and from more polar metabolites.

\section{Case History}

A 53-year-old English woman presented with a three-month history of pain in the right hip and groin, and a radiograph of the pelvis showed Looser zones in the right pubis. An iliac crest biopsy showed typical osteomalacia, and she was referred for detailed metabolic investigation. It transpired that she had been taking glutethimide (Doriden) $500 \mathrm{mg}$ at night on a regular basis for 10 years because of insomnia. Her usual diet was carefully reviewed and the vitamin D content calculated with the aid of the tables of McCance and Widdowson (1967). The value obtained was $82 \mathrm{IU}$ a day. The patient appeared to have had very little exposure to sunlight.

\section{INVESTIGATIONS}

Serum calcium values ranged from 8.4 to $9.1 \mathrm{mg} / 100 \mathrm{ml}$, serum phosphate from 2.3 to $3.2 \mathrm{mg} / 100 \mathrm{ml}$. The serum alkaline phosphatase was 50 K.A. units $/ 100 \mathrm{ml}$ and isoenzyme studies indicated that $70 \%$ was of bone and $30 \%$ of liver origin. The theoretical renal phosphate threshold was normal $(2 \cdot 7 \mathrm{mg} / 100 \mathrm{ml})$. The calcium balance indicated a net loss (fig. 1). The haemoglobin was $14.0 \mathrm{~g} / 100 \mathrm{ml}$, serum $B_{12} 1,000 \mathrm{pg} / \mathrm{ml}$, red cell folate 230 $\mathrm{ng} / \mathrm{ml}$; faecal fat excretion was $1.7 \mathrm{~g} / 24 \mathrm{hr}$, and the barium follow through and jejunal biopsy showed nothing abnormal, thereby excluding malabsorption. Renal function was normal, as evidenced by a blood urea of $20 \mathrm{mg} / 100 \mathrm{ml}$, a creatinine clearance of 76 $\mathrm{ml} / \mathrm{min}$, and normal findings on an ammonium chloride test.

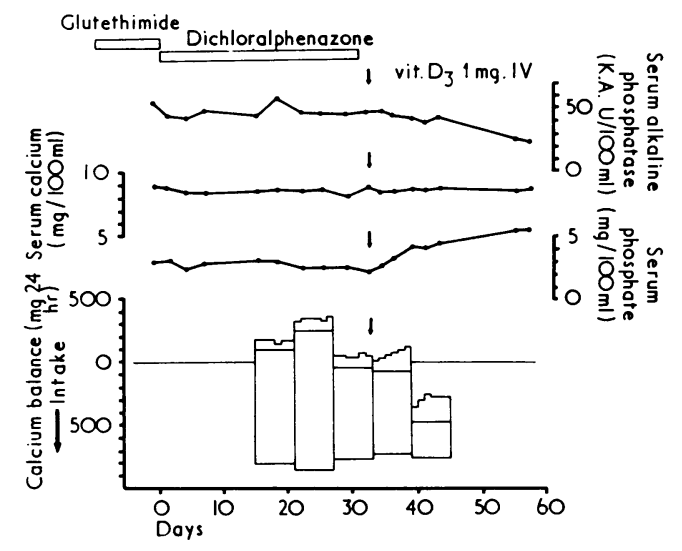

FIG. 1-Response of calcium balance, alkaline phosphatase, and serum phosphate to the intravenous administration of vitamin $D_{3}$. 
Aminoacaiduria was not present. Investigations of liver function were normal in the following respects: the serum bilirubin was $0.3 \mathrm{mg} / 100 \mathrm{ml}$, bromsulphalein retention was $8 \%$ at $25 \mathrm{~min}$, plasma proteins were normal, aspartate aminotransferase was not raised, mitochondrial antibodies were not detected, and a liver biopsy specimen was normal. However, the serum levels of 5-nucleotidase, gamma-glutamyl transpeptidase, and leucine aminopeptidase were raised (fig. 2). The antipyrine half-life was very short ( 3.2 hours) and excretions of $6 \beta$-hydroxycortisol, $D$-glucarcic acid, and xylulose were found to be increased (fig. 3).

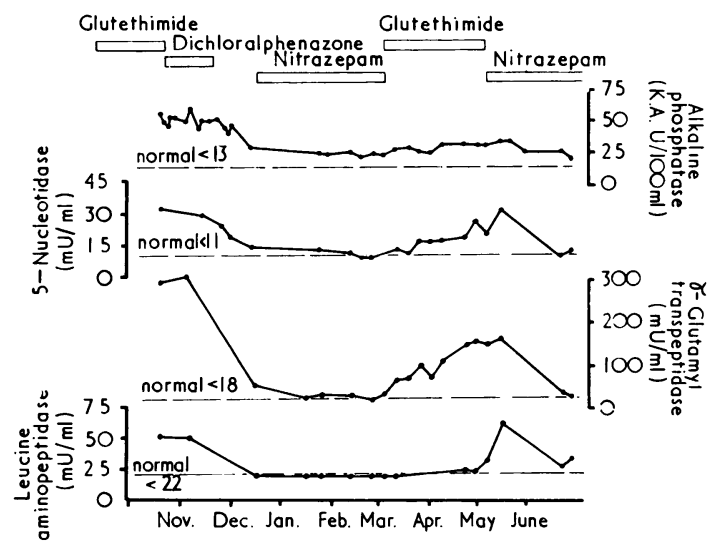

FIG. 2-Changes in serum enzyme concentrations in response to glutethimide.

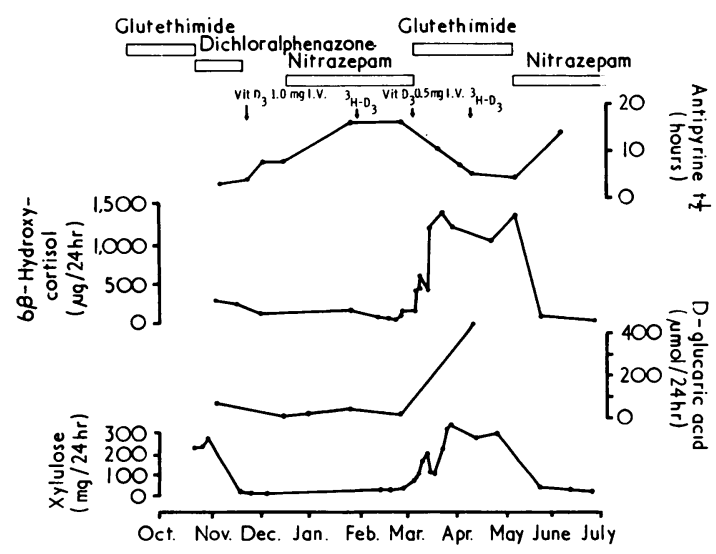

FIG. 3-Changes in antipyrine tz , urinary $6 \beta$-hydroxycortisol, $\mathrm{D}$-glucaric acid, and xylulose in response to glutethimide. The points at which therapeutic vitamin $D_{3}$ and ${ }^{3} \mathrm{H}$ vitamin The points at which therapeutic vitamin $\mathrm{D}_{3}$
$\mathrm{D}_{3}$ tracer were administered are indicated.

On admission to hospital the night sedation had been arbitrarily changed to dichloralphenazone which, like glutethimide, is known to induce hepatic enzymes. Thus, as some form of night sedation was required, it was changed to nitrazepam, which appears to be free from this complication (Beiger et al., 1972). After the withdrawal of glutethimide the antipyrine $t \frac{1}{2}$ rose and the excretion of D-glucaric acid, $6 \beta$-hydroxycortisol, and xylulose fell to normal (fig. 3). At the same time the alkaline phosphatase fell, although the proportions of the isoenzymes remained about the same $(75 \%$ bone, $25 \%$ liver). Serum 5-nucleotidase, gamma-glutamyl transpeptidase, and leucine aminopeptidase also fell (fig. 2).

At this time $1 \mathrm{mg}$ of vitamin $\mathrm{D}_{3}$ was given intravenously. After this, calcium balance became positive, serum phosphate rose (fig. 1), and there was a noticeable improvement in her symptoms.

The metabolism of ${ }^{3} \mathrm{H}$ vitamin $\mathrm{D}_{3}$ was studied on two occasions, firstly, when the patient had not taken glutethimide for 10 weeks and the antipyrine $t \frac{1}{2}$ was normal ( 16.2 hours), and, secondly, four weeks after the reintroduction of glutethimide, when the antipyrine $t \frac{1}{2}$ had again become short ( $5 \cdot 3$ hours).

Shortly before reintroducing glutethimide, as the patient was still symptomatic, it was felt advisable to administer a further $0.5 \mathrm{mg}$ of vitamin $D_{3}$ intravenously.
After the reintroduction of glutethimide the excretion of D-glucaric acid, $6 \beta$-hydroxycortisol, and xylulose rapidly increased (fig. 3), and there was a concomitant rise in serum 5-nucleotidase, gamma-glutamyl transpeptidase, and leucine aminopeptidase (fig 2). After the second ${ }^{3} \mathrm{H} \mathrm{D}_{3}$ study, glutethimide was again withdrawn and replaced by nitrazepam. After this the antipyrine $1 \frac{1}{2}$ rose to 12 hours and the other indices of enzyme induction returned to normal. Therapy with vitamin $D_{3}, 5,000$ $\mathrm{U}$ daily by mouth, was instituted and there was progressive clinical improvement with a decrease in pain and an increase in mobility.

\section{RESULTS OF ${ }^{3} \mathrm{H}$ VITAMIN $\mathrm{D}_{3}$ STUDIES}

The metabolism of ${ }^{3} \mathrm{H} \mathrm{D}_{3}$ was greatly increased when the patient was on glutethimide when compared with the control study (fig. 4). The half-life of radioactivity eluted as $25-\mathrm{OHD}_{3}$ was not appreciably different in the two studies (14 and 15 days).
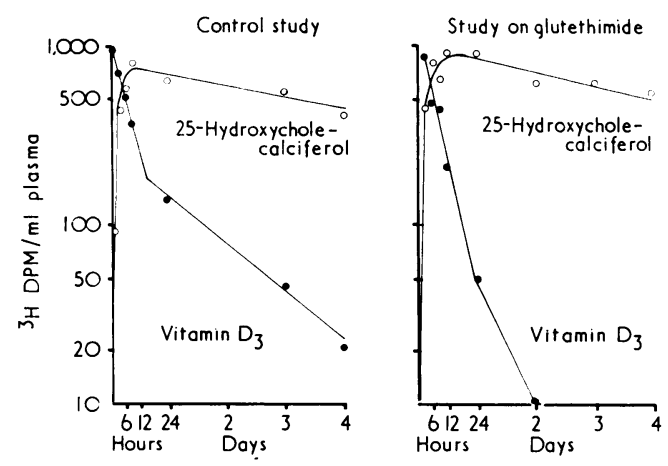

FIG. 4 - Changes in ${ }^{3} \mathrm{H}$ vitamin $\mathrm{D}_{3}$ metabolism in response to glutethimide. DPM = Disintegrations per minute.

\section{Discussion}

Glutethimide, which structurally resembles phenobarbitone, likewise is a potent inducer of hepatic microsomal enzymes (Kato and Chiesara, 1962; Corn, 1966). This patient was extremely sensitive to such enzyme induction, as measured by the effect on antipyrine $t \frac{1}{2}$ (Conney, 1967), 6 $\beta$-hydroxycortisol (Kuntzman et al., 1968), D-glucaric acid (Hunter et al., 1971), and xylulose excretion (Dr. I. S. I. Menzies, unpublished observations).

The enzymes 5-nucleotidase, gamma-glutamyl transpeptidase, and leucine aminopeptidase are increased in liver disease, especially of the obstructive type. Nevertheless, Rosalki et al. (1971) reported raised levels of gamma-glutamyl transpeptidase in patients taking hepatic enzyme inducing drugs. The increase in these enzymes in a patient with otherwise normal liver function strongly suggests that these changes were due to the administration of glutethimide either as a result of enzyme induction or cellular injury.

Both the bone and liver isoenzymes of alkaline phosphatase were raised. Similar findings were reported in some cases of anticonvulsant oesteomalacia by Richens and Rowe (1970). It is possible that in such cases raised alkaline phosphatase levels may not be due entirely to the bone disease, and it is of interest that in this case the liver fraction fell after the withdrawal of glutethimide.

The increased xylulose excretion is likely to be due, at least part, to the increased turnover of glucuronic acid. This would also account for the increased excretion of another metabolite, D-glucaric acid (Hunter et al., 1971). Enzyme-inducing drugs have been shown to enhance the formation of glucuronic acid from glucose (Burns et al., 1957) and galactose (Evans et al., 1960) in animals. Significant excretion of xylulose generally occurs in subjects, usually of Jewish descent, who are homozygous for the condition of essential pentosuria. Margolis (1929) showed that the administration of the enzyme-inducing drug 
amidopyrine greatly increased pentose excretion in such a person. We have been unable to trace any Jewish ancestry in the present case, but it is possible that this patient has a genetic predisposition to pentosuria which renders her more susceptible to this effect of glutethimide.

The osteomalacia in this patient was not due to malabsorption or renal disease. The dietary intake of vitamin $\mathrm{D}$ was assessed as being definitely above $70 \mathrm{IU} /$ day, which is regarded by Dent and Smith (1969) as the lower limit of normal. Hepatic enzymeinduced changes in vitamin $\mathrm{D}$ metabolism may render such a marginal intake inadequate. In this case the metabolism of ${ }^{3} \mathrm{H}$ vitamin $\mathrm{D}_{3}$ was faster when the patient was in the induced state (fig. 4). This occurred despite the therapeutic dose of $0.5 \mathrm{mg}$ of vitamin $\mathrm{D}_{3}$ administered between the two studies, which would have increased the pool size of vitamin $\mathrm{D}$ and thus favour a relatively slower apparent metabolism of the isotope tracer. The greater pool size may have effectively masked a decrease in ${ }^{3} \mathrm{H}-25-\mathrm{OHD}_{3}$ half-life in the second study. The paradox of an increased formation of an active metabolite $\left(25-\mathrm{OHD}_{3}\right)$ resulting in a postulated decrease in biological activity of vitamin $\mathrm{D}$ may be due to an associated increase in excretion of further metabolites of vitamin $\mathrm{D}$ in the bile. This has been shown in enzyme-induced animals by Silver et al. (1972b). Unless there was an adequate intake of vitamin D this would ultimately deplete vitamin D stores, and this is likely to be the mechanism whereby glutethimide produced oesteomalacia in this case. This complication of chronic hypnotic ingestion seems to be a potential risk in any patient receiving a long-term barbiturate-like drug, particularly if in association with a poor diet. Our experience with this patient suggests that the use of nitrazepam should not give rise to this problem.

We would like to thank Dr. G .R. Clarke, of the Department of Rheumatology and Physical Medicine, St. Thomas's Hospital, for referring the case. We are grateful to the following people for the various measurements on the patient: Dr. S. E. Smith, antipyrine; Professor R. V. Brooks, 6 $\beta$-hydroxycortisol; Dr. I. S. I. Menzies, xylulose; Mr. D. A. Stewart (King's College Hospital), D-glucaric acid; Dr. R. R. McSwiney, 5-nucleotidase and routine biochemistry; Dr. L. Ellis, gamma-glutamyl transpeptidase and leucine aminopeptidase; and Dr. P. J. N. Howarth (King's College Hospital), alkaline phosphatase isoenzymes. We are indebted to Dr. G. R. Thompson (Royal Postgraduate Medical School) for his helpful advice and encouragement.

\section{References}

Bieger, R., De Jonge, H., and Loeliger, E. A. (1972). Clinical Pharmacology and Therapeutics, 13, 361 .

Breckenridge, A., Orme, M. L'E., Thorgeirsson, S., Davies, D. S., and Clinical Science, 40, 351.

Brodie, B. B., Axelrod, J., Soberman, R., and Levy, B. B. (1949). Fournal

of Biological Chemistry, 179, 25.
Burns, J. J., Evans, C., and Trousof, N. (1957). Fournal of Biological Chemistry, 227, 785 .

Campbell, D. M. (1962). Biochemical fournal, 82, 34p

Canapa-Anson, R., and Rowe, D. J. F. (1970). Fournal of Clinical Pathology, 23, 499.

Conney, A. H. (1967). Pharmacological Reviews, 19, 317

Corn, M. (1966). Thrombosis et Diathesis Haemorrhagica, 16, 606.

Dent, C. E., Richens, A., Rowe, D. J. F., and Stamp, T. C. B. (1970). British Medical fournal, 4, 69 .

Dent, C. E., and Smith, R. (1969). Quarterly fournal of Medicine, 38, 195.

Evans, C., Conney, A. H., Trousof, N., and Burns, J. J. (1960). Biochimica et Biophysica Acta, 41, 9.

Greenlaw, R. et al. (1972). Clinical Research, 20, 56

Hahn, T. J., Birge, S. J., Scharp, C. R., and Avioli, L. V. (1972). Fournal of

Clinical Investigation, 51, 741.
Hunter, J., Maxwell, J. D., Carella, M., Stewart, D. A., and Williams, R. (1971). Lancet, 1, 572.

Hyde, R. D., Vaughan Jones, R., McSwiney, R. R., and Prunty, F. T. G. (1960). Lancet, 1, 250.

Kato, R., and Chiesara, E. (1962). British fournal of Pharmacology, 18, 29. Kruse, R. (1968). Monatsschrift für Kinderheilkunde, 116, 378.

Kuntzman, R., Jacobson, M., Levin, W., and Conney, A. H. (1968). Biochemical Pharmacology, 17, 565 .

Lawson, D. E. M., Frazer, D. R., Kodicek, E., Morris, H. R., and Williams, D. H. (1971). Nature, 230, 228.

McCance, R. A., and Widdowson, E. M. (1967). Medical Research Council. Special Report Series No. 297

Margolis, J. I. (1929). American fournal of the Medical Sciences, 177, 348.

Mawer, E. B., and Backhouse, J. (1969). Biochemical fournal, 112, 255.

Nagel, W., Willig, F., and Schmidt, F. H. (1964). Klinische Wochenschrift, 42, 447.

Ponchon, G., and De Luca, H. F. (1969). Fournal of Clinical Investigation, 48,1273 .

Prunty, F. T. G., McSwiney, R. R., and Clayton, B. E. (1953). Fournal of Clinical Investigation, 13, 1480

Richens, A., and Rowe, D. J. F. (1970). British Medical fournal, 4, 73.

Rosalki, S. B., Tarlow, D., and Rau, D. (1971). Lancet, 2, 376.

Santangelo, R. P., Fidler, S. M., Mackin, J. F., and Canary, J. J. (1972). Fournal of Clinical Investigation, 51, 84a.

Schmid, F. (1967). Fortschritte der Medizin, 85, 381.

Silver, J., Neale, G., Davies, D. S., Breckenridge, A., and Thompson, G. R. (1972 a). Clinical Science, 42, $12 \mathrm{p}$.

Silver, J., Quill, H., Neale, G., and Thompson, G. R. (1972 b). Clinical

Szasz, G. (1969). Clinical Chemistry, 15, 124.

\title{
Radioimmunoassay of Triiodothyronine in Unextracted Human Serum
}

\author{
R.-D. HESCH, DAVID EVERED
}

British Medical fournal, 1973, 1, 645-648

\section{Summary}

Serum triiodothyronine ( $T-3)$ concentrations have been estimated by radioimmunoassay using unextracted serum. The serum $T-3$ concentrations have been shown to be similar in two separate European populations (0.76-1.67 $\mathrm{ng} / \mathrm{ml}$ ). Raised T-3 values have been observed in all subjects with

Medizinische Universitatsklinik, Göttingen, Germany

R.-D. HESCH, M.D., Endocrinologist

Department of Medicine, University of Newcastle upon Tyne DAVID EVERED, M.D., M.R.C.P., Wellcome Senior Research Fellow in Clinical Science hy perthyroidism. Low values are seen in hypothyroidism although there is some overlap with the normal range. There is a good correlation between serum T-3 and serum thyroxine ( $T-4)$ concentrations, and estimation of $T-3$ seems likely to prove a practical and reliable test of thyroid function.

\section{Introduction}

The major fraction of organic iodine in the circulation is in the form of L-thyroxine (T-4). Although significant amounts of 3,5, 3'-triiodo-L-thyronine (T-3) are present (Gross and Pitt-Rivers, 1952), relatively little is known of the physiological importance of this hormone. A number of techniques have been used to measure the low concentrations of T-3 present in the serum but most of these have suffered from 